\author{
Zh.K. Kairbekov ${ }^{1}$, S.M. Suimbayeva ${ }^{2}$, E.T. Yermoldina ${ }^{2}$, \\ A.S. Maloletnev ${ }^{3}$, I.M. Dzheldybayeva ${ }^{1}$ \\ ${ }^{I}$ Research Institute of New Chemical Technologies and Materials, Almaty, Kazakhstan; \\ ${ }^{2}$ Al-Farabi Kazakh National University, Almaty, Kazakhstan; \\ ${ }^{3}$ Mining Institute NITU MISiS, Moscow, Russia \\ (E-mail: saltanat_suimbayeva@mail.ru)
}

\title{
Hydrogenation of distillate products from liquefaction of coal from Mamyt deposit
}

\begin{abstract}
Coal distillates with boiling point below $360{ }^{\circ} \mathrm{C}$ produced by liquid-phase coal hydrogenation contain substantial amounts of sulfurous ( $\mathrm{S}=0.4-0.8 \%$ ), nitrous $(\mathrm{N}=0.2-0.5 \%)$, oxygenous $(\mathrm{O}=1.5-2 \%)$ and unsaturated compounds (20-25\%). To obtain low-sulfur stable motor fuel with high octane and cetane numbers it is required to process such products applying hydrotreatment processes. The published work contains the results of hydrogenation of coal distillates of Mamyt coal with the boiling point below $360^{\circ} \mathrm{C}$ in the presence of Mo-containing catalysts deposited on the surface of skeletal nickel (Ni-Raney) are presented. It is shown that $3-5 \% \mathrm{Mo} / \mathrm{Ni}-\mathrm{Re}$ catalysts activate the hydrogenation reactions of hetero-atomic and unsaturated compounds at $420{ }^{\circ} \mathrm{C}, 6.0 \mathrm{MPa}$. The content of nitrous bases in hydrogenate in comparison with the primary material reduces from 3.3 to $0.5 \%$; sulfur content reduces from 0.74 to $0.05 \%$; nitrogen from 0.47 to $0.01 \%$. The best hydrotreatment of coal distillate is performed with $5 \% \mathrm{Mo} / \mathrm{Ni}-\mathrm{Re}$ catalyst. In hydrotreated petroleum fractions the amount of paraffinic and olefinic hydrocarbons reduced almost twice and the amount of isoparaffinic hydrocarbons increased more than two times. The diagram for the conversion of the organic matter of paste is proposed. The principal diagram for obtaining components of motor fuels by hydrotreatment of distillate products of liquefaction of Mamyt coal is developed.
\end{abstract}

Keywords: hydrogenation, skeletal nickel, liquefaction, coal, Mamyt deposit, catalyst, coal distillate, motor fuels.

\section{Introduction}

Solid fuels are the potential source of primary materials for provision of the economy of Kazakhstan with organic fuel and materials for chemical and other industries. Presently several foreign countries have developed experimental and pilot plants for production of synthetic liquid fuel from coal [1]. Substantial attention is paid to obtaining components of gasoline and diesel fuel from coal liquefaction products [2, 3].

The Scientific Research Institute of New Chemical Technologies and Materials has developed a technology for liquid-phase coal hydrogenation [4-6] in the mixture with «own» paste-forming agent (1:1) in the presence of active catalysts at hydrogen pressure of $6 \mathrm{MPa}$ at $400-420^{\circ} \mathrm{C}$. In the process it is feasible to obtain a component of high-octane gasoline, jet fuel, diesel and gas-turbine fuel, and valuable chemical products (phenols $\mathrm{C}_{6}-\mathrm{C}_{8}$, nitrogen bases, unsaturated compounds, etc.) Coal distillates with boiling point below $400{ }^{\circ} \mathrm{C}$ produced by liquid-phase coal hydrogenation contain substantial amounts of sulfur $(\mathrm{S}=0.4-0.8 \%)$, nitrogen $(\mathrm{N}=0.2-0.5 \%)$, oxygen $(\mathrm{O}=1.5-2 \%)$ and unsaturated compounds $(20-25 \%)$.

Due to substantial amounts of sulfur, nitrogen, oxygen and unsaturated compounds distillate fractions of coal hydrogenation products cannot be directly used as commercial fuels. To obtain low-sulfur stable motor fuel with high octane and cetane numbers it is required to process such products applying hydrotreatment processes.

The published work contains the results of hydrotreatment of fractions of liquid-phase hydrogenate of brown coal from Mamyt deposit with the boiling point below $360^{\circ} \mathrm{C}$ aimed at obtaining of gasoline components.

\section{Experimental}

The source material comprises coal distillates with boiling point up to $360^{\circ} \mathrm{C}$ obtained by hydrogenation of brown coal from Mamyt at $6.0 \mathrm{MPa}$.

The brown coal from Mamyt deposit had the following properties: $\mathrm{W}^{\mathrm{r}}-9.00 \%, \mathrm{~A}^{\mathrm{C}}-11.31 \%, \mathrm{~A}^{0}-$ $10.31 \%, \mathrm{~V}^{\mathrm{daf}}-34.82 \%, \mathrm{C}^{\mathrm{daf}}-73.06 \%, \mathrm{H}^{\mathrm{daf}}-4.71 \%, \mathrm{~S}^{\mathrm{d}}-0.34 \%, \mathrm{Q}_{\mathrm{B}}^{\mathrm{A}}-29.2 \mathrm{~kJ} / \mathrm{mol}, \mathrm{Q}_{\mathrm{I}}^{\mathrm{r}}-$ $28.0 \mathrm{~kJ} / \mathrm{mol}, \mathrm{Q}_{\mathrm{H}}^{\mathrm{r}}-26.8 \mathrm{~kJ} / \mathrm{mol}, \mathrm{C}: \mathrm{H}-15.5$. 
Hydration process was performed with Mo-containing catalysts applied on the surface of spongy nickel (Ni-Raney). The catalysts have been obtained by treatment with molybdate solution $\left(\mathrm{NH}_{4}\right)_{6} \mathrm{Mo}_{7} \mathrm{O}_{24} \cdot 4 \mathrm{H}_{2} \mathrm{O}$ of the surface of Ni-Raney. The sponge nickel was obtained from Ni-Al (1:1) alloy by treatment with $20 \%$ $\mathrm{NaOH}$ solution at the temperature of boiling water bath.

The elemental composition of the liquid products was determined on the Elementar Vario Micro Cube, and the amount of hydrocarbon composition was determined by the gas-chromatographic method using the Chromatech-5000 chromatograph.

Subsequently, the process of hydrogenation of distillate products obtained by coal liquefaction on applied Mo/Ni-Re catalysts under the conditions of a laboratory flow unit under hydrogen pressure was carried out.

\section{Results and Discussion}

Fractions below $360^{\circ} \mathrm{C}$ obtained after liquefaction were hydrated on the applied Mo/Ni-Re catalysts. The results are shown in Table 1.

$\mathrm{Table} 1$

Results of hydrotreatment of the fractions with boiling point up to $360{ }^{\circ} \mathrm{C}$ on $3-7 \% \mathrm{Mo} / \mathrm{Ni}-\mathrm{Re}$ catalysts $\left(\mathrm{T}=420{ }^{\circ} \mathrm{C}, \mathrm{P}=6.0 \mathrm{MPa}\right)$

\begin{tabular}{|c|c|c|c|c|}
\hline \multirow{2}{*}{ Indicators } & \multirow{2}{*}{$\begin{array}{c}\text { Raw materials } \\
\text { (coal distillate with boil- } \\
\text { ing point up to } 360^{\circ} \mathrm{C} \text { ) }\end{array}$} & \multicolumn{3}{|c|}{ Catalysts } \\
\hline & & $3 \% \mathrm{Mo} / \mathrm{Ni}-\mathrm{Re}$ & $5 \% \mathrm{Mo} / \mathrm{Ni}-\mathrm{Re}$ & $7 \% \mathrm{Mo} / \mathrm{Ni}-\mathrm{Re}$ \\
\hline Density, $\mathrm{g} / \mathrm{cm}^{3}$ & 0.8903 & 0.8597 & 0.8537 & 0.8591 \\
\hline Refractive index, $\eta_{\mathrm{D}}$ & 1.4967 & 1.4836 & 1.4793 & 1.4816 \\
\hline $\begin{array}{l}\text { Content, \%: } \\
\text { Phenolic compounds } \\
\text { Nitrogen compounds }\end{array}$ & $\begin{array}{l}6.6 \\
3.3\end{array}$ & $\begin{array}{c}\text { Absent } \\
0.5\end{array}$ & $\begin{array}{c}\text { Absent } \\
0.5\end{array}$ & $\begin{array}{c}\text { Absent } \\
0.5\end{array}$ \\
\hline \begin{tabular}{|l} 
Element composition, \%: \\
$\mathrm{C}$ \\
$\mathrm{H}$ \\
$\mathrm{S}$ \\
$\mathrm{N}$ \\
$\mathrm{O}$ (by difference) \\
\end{tabular} & $\begin{array}{c}85.53 \\
11.62 \\
0.74 \\
0.47 \\
1.98\end{array}$ & $\begin{array}{c}87.35 \\
12.53 \\
0.08 \\
0.04 \\
\text { Absent }\end{array}$ & $\begin{array}{c}87.21 \\
12.71 \\
0.05 \\
0.01 \\
\text { Absent }\end{array}$ & $\begin{array}{c}87.12 \\
12.73 \\
0.12 \\
0.03 \\
\text { Absent }\end{array}$ \\
\hline $\begin{array}{l}\text { Fractional composition, wt. \%: } \\
\text { before } 180^{\circ} \mathrm{C} \\
180-2500^{\circ} \mathrm{C} \\
250-320^{\circ} \mathrm{C} \\
320-360^{\circ} \mathrm{C}\end{array}$ & $\begin{array}{c}4.9 \\
8.1 \\
33.2 \\
53.8\end{array}$ & $\begin{array}{l}45.3 \\
23.3 \\
18.6 \\
87.2\end{array}$ & $\begin{array}{l}49.5 \\
29.8 \\
16.3 \\
95.6\end{array}$ & $\begin{array}{l}53.7 \\
17.9 \\
18.5 \\
90.1\end{array}$ \\
\hline Losses & 0.5 & 0.6 & 0.2 & 0.3 \\
\hline
\end{tabular}

The primary material contained (\%): phenols -6.6 ; nitrous bases -3.3 ; sulfur -0.74 .

The study results demonstrate that $\mathrm{Mo} / \mathrm{Ni}$-Re catalyst activates hydrogenation reactions of heteroatomic and unsaturated compounds at $420^{\circ} \mathrm{C}$ and $6.0 \mathrm{MPa}$. At the same time the content of phenols reduces from $6.6 \%$ to zero. The content of nitrous bases in hydrogenate in comparison with the primary material reduces from 3.3 to $0.5 \%$; sulfur content reduces from 0.74 to $0.05 \%$; nitrogen from 0.47 to $0.01 \%$. The best hydrotreatment of coal distillate is performed with $5 \% \mathrm{Mo} / \mathrm{Ni}-\mathrm{Re}$ catalyst.

Thus, there is a demonstrated possibility in principle to hydrogenate the fraction with boiling point up to $360{ }^{\circ} \mathrm{C}$ obtained from distillates of Mamyt coal in soft conditions on Mo-catalyst applied on sponge nickel.

Individual and group hydrocarbon composition of petroleum fraction was studied by chromatographic method. The study results are shown in Table 2. According to the data of gas chromatographic analysis petroleum fraction obtained by hydrogenation of coal distillates on $5 \% \mathrm{Mo} / \mathrm{Ni}-\mathrm{Re}$ catalyst has substantial changes in composition comparing with petroleum fraction obtained by coal hydrogenation on zeolite.

The readings of petroleum fraction chromatogram shows 10 paraffin, 59 isoparaffin, 47 aromatic, 37 naphthene, 45 olefin, and 16 cyclo-olefin hydrocarbons.

According to the obtained results (see Table 2) proportion of paraffin hydrocarbons reduces from $35.8 \%$ to $20.7 \%$. It is essential to note the reduction of amount of heptane (from 5.25 to $3.21 \%$ ), octane 
(from 7.47 to $4.32 \%$ ), nonane (from 7.57 to $0.35 \%$ ), decane (from 7.60 to $1.71 \%$ ), and undecane (from 5.97 to $0.88 \%$ ).

Group hydrocarbon composition of distillate fractions with boiling point up to $180{ }^{\circ} \mathrm{C}$

\begin{tabular}{|l|c|c|}
\hline \multirow{2}{*}{ Hydrocarbons } & \multicolumn{2}{|c|}{ Catalyst } \\
\cline { 2 - 3 } & Raw materials & $5 \% \mathrm{Mo} / \mathrm{Ni}-\mathrm{Re}$ \\
\hline Paraffins & 35.8 & 22.7 \\
\hline Isoparaffins & 16.5 & 30.1 \\
\hline Aromatic & 25.0 & 21.8 \\
\hline Naphthenes & 13.9 & 15.9 \\
\hline Olefins & 8.3 & 4.3 \\
\hline Cycloolefins & 0.5 & 4.9 \\
\hline Dienes & - & 0.3 \\
\hline Octane number & 69.4 & 72.7 \\
\hline
\end{tabular}

In the hydrated gasoline there were substantial changes in the amount of isoparaffin hydrocarbons. If gasoline fraction from coal liquefaction on zeolite catalyst contained $16.5 \%$ of isoparaffin hydrocarbons, hydrated gasoline the content was $30.1 \%$. The content of some isoparaffin hydrocarbons increased in 2 to 5 times. The amount of 2,4-dimethylpentane in the presence of $\mathrm{Mo} / \mathrm{Ni}-\mathrm{Re}$ catalyst was $1.32 \%$, in primary gasoline $-0.027 \%$; the content of 3-methylpentane after hydration was $2.78 \%$, and in primary gasoline only 0.76. In comparison with the octane number of primary gasoline (69.4) the octane number of gasoline hydrated on $5 \% \mathrm{Mo} / \mathrm{Ni}-\mathrm{Re}$ catalyst increased to 72.7. If in gasoline obtained from coal liquefaction in zeolite presence the content of aromatic hydrocarbons was $25.0 \%$, then on $5 \% \mathrm{Mo} / \mathrm{Ni}-\mathrm{Re}$ catalyst it reduced to $21.8 \%$. The content of benzene on the applied catalyst reduced. In gasoline fraction obtained by coal hydrogenation on zeolite it was $0.48 \%$ and on applied Mo/ $\mathrm{Ni}-\mathrm{Re}$ catalyst its content was $0.24 \%$. The obtained data are in compliance with the recent requirements to the quality of motor fuels.

Also, hydrated gasoline contained olefin, cyclo-olefin and diene hydrocarbons. The amount of olefin hydrocarbons reduced from 8.3 to $4.3 \%$. If gasoline from coal liquefaction in zeolite presence contained 2,4-dimethyl-1-pentene, trans-2-hexene, 4-methyloctene, trans-3-nonene, 6-dodecene, they are not contained in hydrated gasoline. The content of cyclo-olefins in hydrated gasoline is much higher than in primary gasoline.

On the basis of the obtained results (Tables 1,2) a flow chart for conversion of organic paste mass through hydrogenation was prepared (Fig. 1).

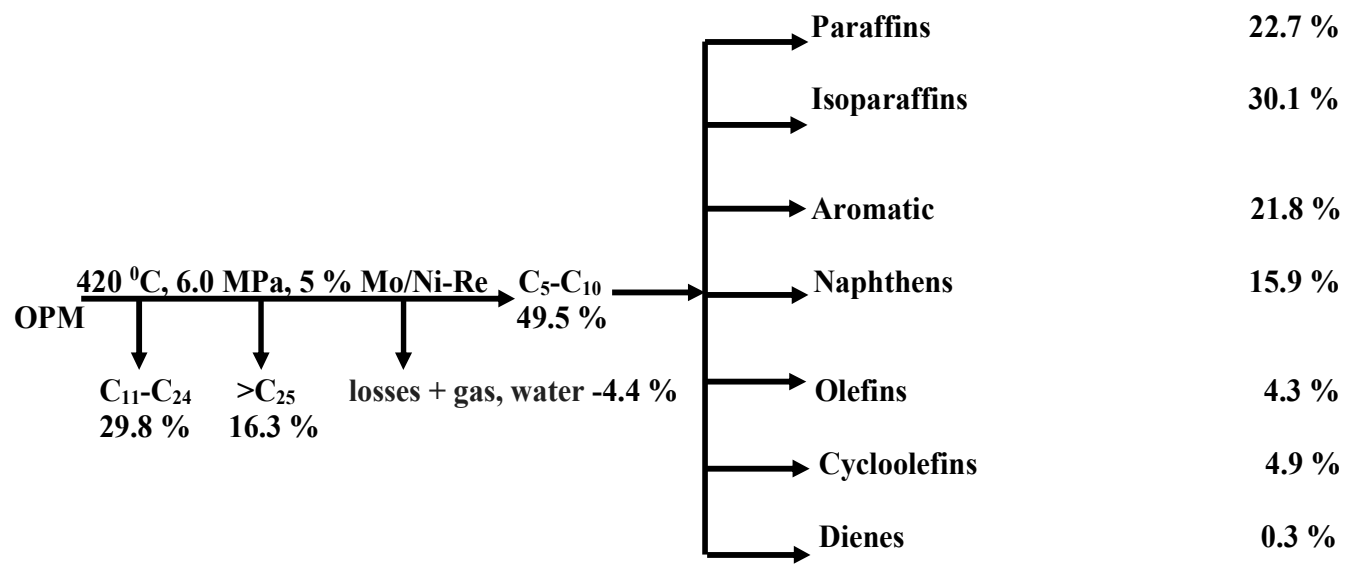

Figure 1. Flow chart for conversion of organic paste mass (OPM) during hydrogenation of distillate product obtained by coal liquefaction

Based on the research carried out, as well as the previously published data $[4,5]$, a principal diagram for obtaining motor fuel components from liquefied brown coal products of the Mamyt deposit was developed (Fig. 2). 


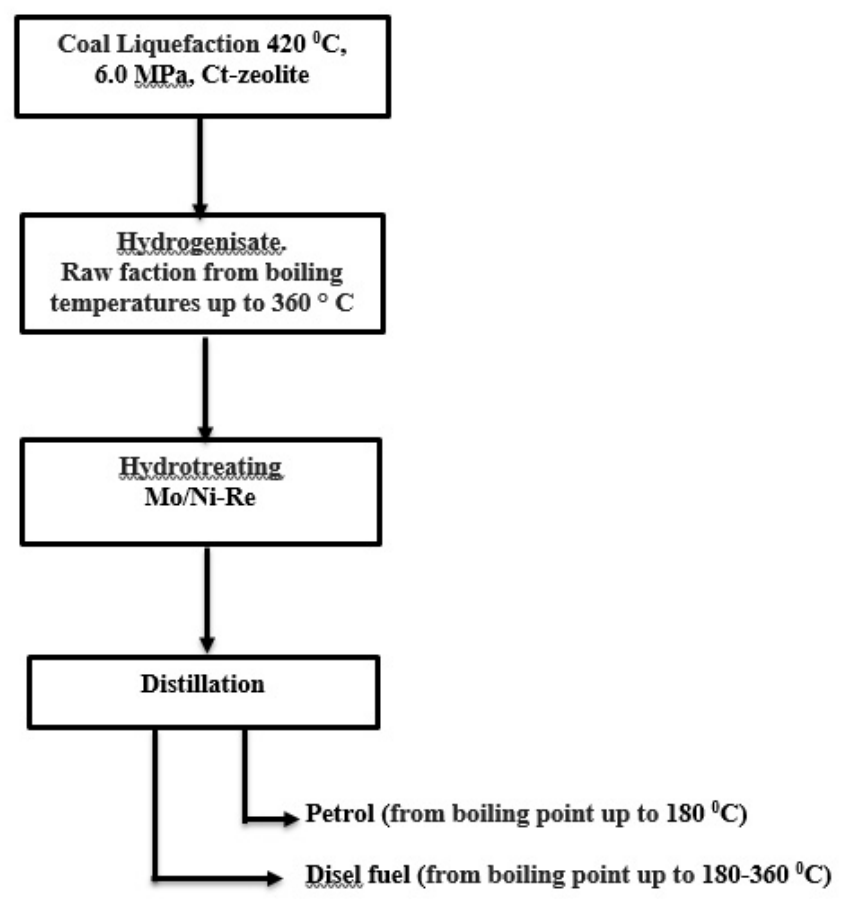

Figure 2. Flow chart for production of motor fuel components by hydrogenation of coal distillates

\section{Conclusions}

As the result of hydration of distillate products obtained after coal liquefaction of the applied Mo/Ni-Re catalysts, for the first time was demonstrated that there is potential possibility of hydration of gasoline fraction obtained from Mamyt coal distillates on Mo catalyst applied on spongy nickel. The best hydrotreatment of coal distillate is performed with $5 \% \mathrm{Mo} / \mathrm{Ni}-\mathrm{Re}$ catalyst. The diagram for the conversion of the organic matter of paste is drawn and the principal diagram for obtaining the motor fuel components by hydrogenation of the liquefaction products of Mamyt coal is proposed.

\section{References}

1 Комплексная переработка углей и повышение эффективности их использования: каталог-справ. / под общ. ред. В.М. Щадова. — М.: НТК «Трек», 2007. — 292 с.

2 Печуро Н.С. Химия и технология синтетического жидкого топлива и газа: учеб. пособие / Н.С. Печуро, В.Д. Капкин, О.Ю. Песин. - М.: Химия, 1986. - 352 с.

3 Еремина А.О. Получение дизельного топлива из бурого угля Канско-Ачинского бассейна / А.О. Еремина, А.А. Кричко, М.К. Юлин // Химия твердого тела. — 1986. — № 1. — С. 73-81.

4 Каирбеков Ж.К. Теория и практика переработки угля / Ж.К. Каирбеков, В.С. Емельянова, К.А. Жубанов, Ж.К. Мылтыкбаева, Б.Б. Байжомартов. - Алматы: Білім, 2013. - 496 с.

5 Каирбеков Ж.К. Комплексная переработка бурых углей Центрального Казахстана / Ж.К. Каирбеков, М.Т. Токтамысов, Н. Жалгасулы, Ж.Т. Ешова. - Алматы: Қазақ ун-ті, 2014. - 278 с.

6 Каирбеков Ж.К. Комплексная переработка бурых углей Восточного Казахстана / Ж.К. Каирбеков, Е.К. Аубакиров, Ж.К. Мылтыкбаева, Н.Т. Смагулова. - Алматы: Қазақ ун-ті, 2017. - 369 с. 


\title{
Ж.К. Каирбеков, С.М. Суймбаева, Э.Т. Ермолдина, А.С. Малолетнев, И.М. Джелдыбаева \\ Мамыт кен орны көмірін сұйылтудан алынған дистиллят өнімдерін гидрогендеу
}

\begin{abstract}
Көмірді сұйық фазада гидрогендеу арқылы алынған қайнау температурасы $360^{\circ} \mathrm{C}$ болатын көмірлі дистилляттардың құрамында көптеген күкіртті $(\mathrm{S}=0.4-0,8 \%)$, азотты $(\mathrm{N}=0,2-0,5 \%)$, оттекті $(\mathrm{O}=1,5-2 \%)$ және қанықпаған (20-25\%) қосылыстар болады. Жоғары октанды және цетанды саны бар аз күкіртті тұрақты мотор отын алу үшін шикізатты гидротазалау процестерін қолдана отырып, қайта өңдеу қажет. Макалада қаңқалы никель бетіне отырғызылған Мо-құрамдас катализаторлар қатысында қайнау температурасы $360^{\circ} \mathrm{C}$ болатын мамыт көмірінің дистилляттарын гидрогендеудің нәтижелері көрсетілген. $420{ }^{\circ} \mathrm{C}$ температурада, 6,0 МПа қысымда 3-5 \% Mo/Ni-Re катализаторлары гетероатомды және қанықпаған қосылыстарды гидрогендеу реакциясын белсендіретіні көрсетілген. Шикізатпен салыстырғанда гидрогенизаттағы азотты негіздердің (\%) құрамы 3,3-тен 0,5-ке, ал күкірт құрамы 0,74-тен 0,05 \%-ға, азот 0,47-ден 0,01 \%-ға төмендейді. Көмірлі дистилляттардың тазалануы $5 \% \mathrm{Mo} / \mathrm{Ni}-\mathrm{Re}$ катализаторда жақсы жүреді. Гидротазаланған бензин фракциясында парафин және олефин көмірсутектердің саны 2 есе азаяды, ал изопарафин көмірсутектері 2 есе жоғарлайды. Пастаның органикалық массасының түрленуінің сызба-нұсқасы мен Мамыт кен орны көмірін сұйылтудың дистиллят өнімдерін гидротазалау нәтижесінде мотор отын компоненттерін алудың принципиалды сызба-нұсқасы ұсынылған.
\end{abstract}

Кілт сөздер: гидрогендеу, қаңқалы никель, сұйылту, көмір, Мамыт кенорны, катализатор, көмірлі дистиллят, мотор отыны.

\author{
Ж.К. Каирбеков, С.М. Суймбаева, Э.Т. Ермолдина, \\ А.С. Малолетнев, И.М. Джелдыбаева
}

\section{Гидрогенизация дистиллятных продуктов ожижения угля Мамытского месторождения}

\begin{abstract}
Угольные дистилляты с температурой кипения до $360^{\circ} \mathrm{C}$, полученные при жидкофазной гидрогенизации угля, содержат в своем составе значительные количества сернистых $(\mathrm{S}=0.4-0,8 \%$ ), азотистых $(\mathrm{N}=0,2-0,5 \%)$, кислородных $(\mathrm{O}=1,5-2 \%)$ и непредельных $(20-25 \%)$ соединений. Для получения малосернистого стабильного моторного горючего с высоким октановым и цетановым числами это сырье необходимо подвергать переработке с применением процессов гидроочистки. В статье приведены результаты гидрогенизации угольных дистиллятов мамытского угля с т. кип. до $360{ }^{\circ} \mathrm{C}$ в присутствии Мо-содержащих катализаторов, нанесенных на поверхность скелетного никеля (Ni-Ренея). Показано, что 3-5 \% Mo/Ni-Re катализаторы активируют реакции гидрогенизации гетероатомных и непредельных соединений при $420^{\circ} \mathrm{C}, 6,0$ МПа. Содержание азотистых оснований в гидрогенизате по сравнению с сырьем уменьшается с 3,3 до 0,5\%, содержание серы - с 0,74 до 0,05\%, а азота - с 0,47 до $0,01 \%$. Наибольшая гидроочистка угольного дистиллята осуществляется на $5 \%$ $\mathrm{Mo} / \mathrm{Ni}-\mathrm{Re}$ катализаторе. В гидроочищенной бензиновой фракции количество парафиновых и олефиновых углеводородов уменьшилось почти в два раза, а изопарафиновых углеводородов увеличилось более чем в два раза. Предложена схема превращения органической массы пасты. Разработана принципиальная схема получения компонентов моторных топлив путем гидроочистки дистиллятных продуктов ожижения мамытского угля.
\end{abstract}

Ключевые слова: гидрогенизация, скелетный никель, ожижение, уголь, Мамытское месторождение, катализатор, угольный дистиллят, моторные топлива.

\section{References}

1 Shchadov, V.M. (Eds.). (2007). Kompleksnaia pererabotka uhlei i povyshenie effektivnosti ikh ispolzovaniia [Complex processing of coals and increasing the efficiency of their use]. Moscow: NTK «Trek» [in Russian].

2 Pechuro, N.S., Kapkin, V.D., \& Pesin O.Yu. (1986). Khimiia i tekhnolohiia sinteticheskoho zhidkoho topliva $i$ haza [Chemistry and Technology of Synthetic Liquid Fuel and Gas]. Moscow: Khimiia [in Russian].

3 Yeremina, A.O., Krichko, A.A., \& Yulin, M.K. (1986). Poluchenie dizelnoho topliva iz buroho uhlia Kansko-Achinskoho basseina [Obtaining diesel fuel from brown coal of the Kansk-Achinsk basin]. Khimiia tverdoho topliva - Chemistry of solid fuel, 1 , 73-81 [in Russian].

4 Kairbekov, Zh.K., Yemelianova, V.S., Zhubanov, K.A., Myltykbayeva, Zh.K., \& Bayzhomartov, B.B. (2013). Teoriia $i$ praktika pererabotki uhlia [Theory and practice of coal processing]. Almaty: Bilim [in Russian]. 
5 Kairbekov, Zh.K., Toktamysov, M.T., Zhalgasuly, N., \& Yeshova, Zh.T. (2014). Kompleksnaia pererabotka burykh uhlei Tsentralnoho Kazakhstana [Complex processing of brown coals of Central Kazakhstan]. Almaty: Qazaq universiteti [in Russian].

6 Kairbekov, Zh.K., Aubakirov, Ye.K., Myltykbayeva, Zh.K., Smagulova, N.T. (2017). Kompleksnaia pererabotka burykh uhlei Vostochnoho Kazakhstana [Complex processing of brown coals of East Kazakhstan]. Almaty: Qazaq universiteti [in Russian]. 